
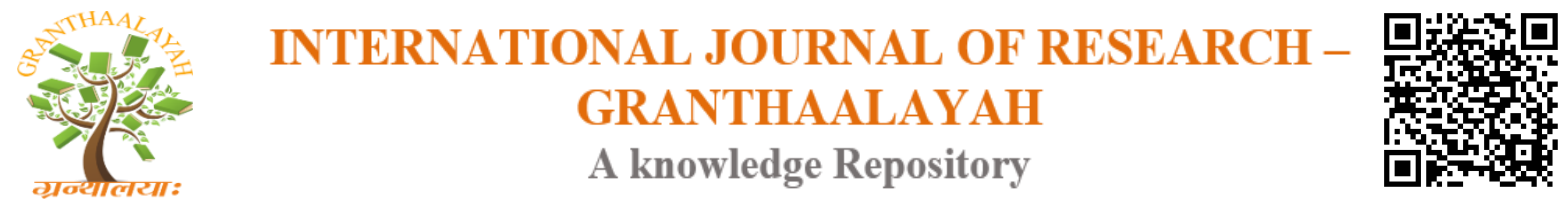

Science

\title{
PHYSICO-MECHANICAL CHARACTERISATION OF WOOD PLASTIC COMPOSITES PRODUCED FROM INDIGENOUS TREES IN NIGERIA
}

\author{
Akinfiresoye W. A ${ }^{* 1}$, Olukunle O. $\mathrm{J}^{2}$, Oyerinde A. $\mathrm{S}^{3}$, Akintade A. A ${ }^{4}$, Olutayo L. A ${ }^{5}$ \\ ${ }^{* 1,2,3,4,5}$ Department of Agricultural and Bio-Environmental Engineering Technology, \\ Rufus Giwa Polytechnic, Owo, Ondo State, Nigeria
}

\begin{abstract}
Wood and plastic wastes are endangering our environments in Nigeria today. These waste materials by this study were recycled into Wood Plastic Composites (WPC) by mixing Sawdust (SD) each of Milicia exels, Ceiba petandra and Cola gigantia with polyethylene terephthalate (PET) plastic wastes using weight based ratios 20:80, 30:70 and 40:60 in a locally fabricated extruder. The melted PET and SD mixture were fed into the extruder already preheated to $190^{\circ} \mathrm{C}$ temperature. The WPC samples were collected into a rectangular mould and compressed to dimension $125 \mathrm{~mm} \times 12.7 \mathrm{~mm} \times 3.2 \mathrm{~mm}$ and $25.4 \mathrm{~mm} \times 12.7 \mathrm{~mm} \times 12.7 \mathrm{~mm}$ based on ASTM D695 and ASTM D790. Samples were allowed to cool down before subjecting them to physical and mechanical tests. The impact of wood type and mix ratio on the physical and mechanical properties of the WPC (water absorption, thickness swelling, linear expansion, modulus of rupture and elasticity) were investigated using analysis of variance at significant difference $(\mathrm{P} \leq$ 0.05). The SD/PET mix ratio of 20:80 and 40:60 of Milicia exels ranked first in terms of physical and mechanical test respectively. This study shows that there is a future for WPC production in Nigeria for external and internal building applications.
\end{abstract}

Keywords: Recycled PET; Sawdust; Extruder; Water Absorption; Thickness Swelling; Linear Expansion; Modulus of Rupture; Modulus of Elasticity.

Cite This Article: Akinfiresoye W. A, Olukunle O. J, Oyerinde A. S, Akintade A. A, and Olutayo L. A. (2018). "PHYSICO-MECHANICAL CHARACTERISATION OF WOOD PLASTIC COMPOSITES PRODUCED FROM INDIGENOUS TREES IN NIGERIA.” International Journal of Research - Granthaalayah, 6(2), 182-196. https://doi.org/ 10.5281/zenodo.1189263.

\section{Introduction}

Wood waste from sawmills and other wood-processing factories are poorly disposed in our environments today. The same goes for plastic water bottles which are either discharged into streams, canals and rivers or used for land filling and in some cases incinerated. These waste products blocked drainage systems causing flooding and land degradation. According to the study carried out by Kehinde et al. (2014), prominent environmental problems caused by the 
poor management of wood waste include emission into the air of toxic and non-toxic particulates. An emission from veneer dryer machines affects the workers and others living in the vicinity and is a serious health hazard. Instead of allowing these waste materials to continue to cause environmental pollution and hazards to human health, they can be recycled to form new and useful products especially where alternatives are been sought for virgin materials (Winnandy et al., 2004).

Wood plastic composite (WPC) is a product that could be obtained from the mixture of plastic and wood (Mokhtar, 2010). This can be achieved by mixing wood wastes with plastic matrix to produce products that can be utilized as components in construction for interior and exterior applications (Olufemi and Armando 2017). As production and use of plastic has increased over the years, a large amount of plastic waste has accumulated in the environment. As a durable material, it is also persistent. Recycling and recovery rates may be improving, but the actual amount of plastic waste produced remains roughly the same and adds to existing waste (Ugoamadi and Ihesiulor, 2011). There is little information on the amounts, rates, fate or impacts of plastic waste on land, whereas there has been a major effort to quantify impacts on shorelines and sea (Lee and Hae, 2011). Plastic waste has several impacts on the health of ecosystems and humans being non-biodegradable. Adhikary et al. (2008), stated that a large amount of wood waste is generated from wood industry at different stages of the processing of wood; which is disposed mostly in landfills. Poor management and incineration of wood waste caused environmental and air pollution through the emission of toxic and non-toxic particulates and smoke (Kehinde et al., 2014). The wood and plastic wastes can therefore be recycled to form useful products thereby eliminating environmental pollution as well (Akinfiresoye et al., 2017). This new product is called wood plastic composites (WPC). Wood plastic composite (WPC) are materials made from a combination of saw dust, thermoplastic resin and chemical additives (Clemons, 2002). The wood raw material used in wood-polymer composites is either wood flour or wood fibres (Michael and Karl, 1999). Due to the higher cost and difficulties in processing, especially in feeding and metering, wood fibres are not used as much as wood flour in commercial manufacture of wood polymer composites (Stark, 1999). The thermal stability of wood is $210^{\circ} \mathrm{c}$ (Michael and Karl, 1999). Because of this, only polymers with processing temperatures lower than $210^{\circ} \mathrm{c}$ are typically used in WPC production (Stark, 1999). The common adopted sizes of wood utilized for the production of WPC range from 50 to 700 micrometers; where increasing particle size results in better flow of molten composite, lower mould shrinkage, and higher flexural modulus (Klyosov, 2007). Virgin thermoplastics, such as high and low density polyethylene (HDPE and LDPE), polypropylene (PP), and polystyrene (PS), are the best known WPC products (Nair et al., 2001; Harper and Wolcott 2004; Bengtsson et al., 2005). Adhikary, et al. (2008) observed that WPC can also be produced from recycled plastic and wood flour. They observed that WPC produced using HDPE has superior dimensional stability and equivalent tensile and flexural properties when compared to virgin HDPE. Contrarily, Yeh, et al. (2009) observed that wood with recycled plastics resulted in poor and variable mechanical properties as compared to the relevant virgin plastics. They added that unlikable odour is obtained from recycled material which could be avoided by adding a thin layer of virgin polymer. In line with this, Najafi, et al. (2007) have tested water absorption and thickness swelling of WPC obtained from sawdust and recycled and virgin plastic; HDPE and PP. The test consisted of $2 \mathrm{hr}$ and $24 \mathrm{hr}$ water submersion tests. The results showed that recycled WPC absorbed more than virgin, PP absorbs water more than HDPE, and the mix of recycled HDPE 
and PP absorbed the maximum. The two main adopted techniques in the production of WPCS are extrusion and injection moulding. The extrusion process produces continuous linear profiles via forcing a melted thermoplastic through a die; on the other hand, the injection moulding process produces three-dimensional items which minimize the stages of post-manufacturing (Migneault et al., 2009). Soury et al., (2009), found an advantage of adopting extrusion instead of injection moulding represented in the high challenge of producing one piece pallet in injection moulding which could make the wood in the composite burnt. The majority of the WPC physical and mechanical properties are depending on mostly on the interaction developed between wood and the plastic. One of the ways to increase this interaction is adding an additive which enhances the compatibility between hydrophilic wood and hydrophobic plastic allowing the formation of single-phase composite (Wechslera and Hiziroglub, 2007). The additives include lubricants, rheology modifiers and dispersion aids in wood-filled PVC composites. The aims are to improve its quality and surface appearance as well as improvement in the processing. (Struktol, 2005). The most famous mineral additive utilized is the talc and calcium carbonate (Klyosov 2007; Adhikary et al., 2008), and (Fabiyi et al., 2008). WPC has become currently an important address of research that gained popularity over the last decade especially with its properties and advantages that attracted researchers such as: high durability, low maintenance, acceptable relative strength and stiffness, fewer prices relative to other competing materials, and the fact that it is a natural resource (Bengtsson and Oksman, 2006; Winandy et al., 2004). Other advantages have been strength points (Wechsler and Hiziroglu, 2007). The resistance in opposition to biological deterioration especially for outdoor applications where untreated timber products are not suitable, the high availability of fine particles of wood waste is a main point of attraction which guarantees sustainability, improved thermal and creep performance relative to unfilled plastics. WPC are used in structural building applications such as profiles, sheathings, decking, roof tiles, and window trims. Various researchers have used saw dust from indigenous trees and waste nylon and HDPE especially, to produce WPCS using electric hot plates compounding techniques (Olufemi and Armando, 2017; Oluyege et al., 2017; Aina et al., 2016; Aina et al., 2014; Izekor and Mordi, 2014; Aina et al., 2013; Khandkar et al., 2013; Mokhtar, 2010), but, not much has been done using other type of indigenous trees such as Cola gigantia (Oporoporo) which is very common in south-western part of nigeria with PET type of plastic using locally fabricated extruder for the production. Oladejo and Omoniyi (2017) however produced WPC using locally fabricated extruder by combining PET with another indigenous tree, Anogeissus leiocarpus (Ayin) which is different from the trees under this research. The analysis of the results of the physical and mechanical properties of WPC produced from this simple technology will be used to compare with related researches already conducted.

\section{Materials and Methods}

The research was carried out in the workshop and laboratory of the department of Agricultural and Environmental Engineering of the Federal University of Technology, Akure, Ondo State, Nigeria and Mechanical Engineering department laboratory of Elizade University, Ilaramokin, Ondo State, Nigeria. The sawdust (SD) of Milicia exels, Ceiba petandra and Cola gigantia were collected from sawmill in Onyearugbulem road, Akure, Ondo State while the polyethylene terephthalate, PET (used plastic water bottles) were collected from the refuse bins of Ade super hotel, Ilesha Road, Akure, Ondo State, Nigeria. The waste plastic bottles were sorted, cleaned, dried and shredded into $1.89 \mathrm{~mm}^{2}$ average size using locally fabricated plastic shredder 
(Akinfiresoye et al., 2017). The sawdust were sieved using standard wire mesh size of $2.00 \mathrm{~mm}$ and air dried to a moisture content of $12 \%$ using hygrometer to measure the moisture reduction. Weight based (in grams) of three mixing ratios of sawdust-plastic (SD/PET) were chosen; 40:60, 30:70 and 20:80 based on the design of the experiment forming three batches in one group. For the first batch in the first group, SD was weighed to $210 \mathrm{~g}$ using electronic digital weighing balance while the PET was weighed to $84 \mathrm{~g}, 63 \mathrm{~g}$ and $42 \mathrm{~g}$ representing $40 \%, 30 \%$ and $20 \%$ of $210 \mathrm{~g}$ of the first SD/PET mix ratio of 40:60, 30:70 and 20:80 respectively. Next was the second group of SD weighed to $195 \mathrm{~g}$ while PET was weighed to $78 \mathrm{~g}, 59 \mathrm{~g}$ and $39 \mathrm{~g}$ representing the SD/PET mix ratio of 40:60, 30:70 and 20:80 respectively. The third and last group was SD weighing $180 \mathrm{~g}$ and the correspondent PET weights of $72 \mathrm{~g}, 54 \mathrm{~g}$ and $36 \mathrm{~g}$ representing the SD/PET mix ratio of 40:60, 30:70 and 20:80 respectively. For the first batch in the first group, $\mathrm{SD} / \mathrm{PET}$ of 40:60 mix ratio; SD of weight $210 \mathrm{~g}$ was allowed to melt in the melting and mixing chamber of the extruder which had been preheated to $190^{\circ} \mathrm{c}$ through $3.5 \mathrm{kw}$ heat band. Thereafter, $84 \mathrm{~g}$ of PET representing $40 \%$ of $210 \mathrm{~g}$ of SD were added and mixed together and the slurry formed was fed into the extruder already preheated and maintained at temperature $190^{\circ} \mathrm{c}$ from $4.8 \mathrm{kw}$ heat band. The extruder kneaded the composites thoroughly at speed $277 \mathrm{rpm}$ (Akinfiresoye et al., 2017) and the extrudate collected at the exit end of the extruder into a mould of dimension $16.5 \mathrm{~mm} \times 36.5 \mathrm{~mm} \times 145.5 \mathrm{~mm}$ which was hot pressed at $120^{\circ} \mathrm{c}$ and $1.12 \mathrm{~N} / \mathrm{mm}^{2}$ force to a thickness of $12.7 \mathrm{~mm}$ using infrared thermometer and calibrated hydraulic press locally fabricated. The WPC produced was allowed to cool down before removal. This procedure was repeated for the second batch in the first group; SD of weight $210 \mathrm{~g}$ mixed with PET of weight $63 \mathrm{~g}$ for the SD/PET mix ratio 30:70, followed by the third batch in the first group; SD of weight $210 \mathrm{~g}$ and PET of weight $42 \mathrm{~g}$ for the SD/PET mix ratio of 20:80. Three specimens were produced for each of the batches, making nine specimens for each group and twenty seven specimens for the three groups under investigation. The physical properties test of the WPC produced carried out on each of the samples were, water absorption, thickness swelling and linear expansion. The instruments used in carrying out this test include electronic digital weighing balance, ruler, vernier calliper, micrometer screwgauge, stopwatch, hacksaw, plastic bowls and calculator. For the mechanical properties test, the samples were trimmed to dimensional size $12.7 \mathrm{~mm} \times 12.7 \mathrm{~mm} \times 25.4 \mathrm{~mm}$ and $3.2 \mathrm{~mm} \times 12.7 \mathrm{~mm} \times 125 \mathrm{~mm}$ based on ASTM D 790 and ASTM D 695 in preparation for flexural and compression tests, modulus of rupture and modulus of elasticity respectively. The instrument used to carry out this test was electronic universal mechanical testing machine (Shinjin WDW -50 D) controlled by a micrometer computer attached to the machine to give the reading at cross head speed of $10 \mathrm{~mm} / \mathrm{min}$ at the laboratory of mechanical engineering department of Elizade University, Ilaramokin, Ondo State, Nigeria. The physical tests were calculated according to equations 1, 2 and 3 (Aina et al., 2014).

\section{Water Absorption}

$\mathrm{WA}(\%)=\frac{m_{2}-m_{1}}{m_{1}} \times 100$

Where:

WA $(\%)$ is water absorption

$\mathrm{m}_{2}$ is weight $(\mathrm{g})$ of the specimen after soaking

$\mathrm{m}_{1}$ is weight $(\mathrm{g})$ of the specimen before the soaking. 


\section{Thickness Swelling}

$$
\text { TS }(\%)=\frac{T_{2}-T_{1}}{T_{1}} \times 100
$$

Where:

TS $(\%)$ is thickness swelling

$\mathrm{T}_{1}$ is thickness before soaking $(\mathrm{mm})$

$\mathrm{T}_{2}$ is thickness after soaking $(\mathrm{mm})$

\section{Linear Expansion}

$$
\operatorname{LE}(\%)=\frac{L_{2}-L_{1}}{L_{1}} \times 100
$$

Where:

$\mathrm{LE}(\%)$ is linear expansion

$\mathrm{L}_{1}$ is final length before soaking $(\mathrm{m})$

$\mathrm{L}_{2}$ is final length after soaking $(\mathrm{m})$

While the mechanical properties were calculated from equations 4 and 5 according to Izekor and Mordi (2014).

$M O R=\frac{3 P L}{2 b d^{2}}$

Where:

MOR is the modulus of rupture $\left(\mathrm{N} / \mathrm{mm}^{2}\right)$

$\mathrm{P}$ is the ultimate failure load $(\mathrm{N})$

$\mathrm{L}$ is the length of WPC sample between the machine support (mm)

$\mathrm{b}$ is width of the WPC sample (mm)

$\mathrm{d}$ is thickness of the WPC sample $(\mathrm{mm})$

And

$$
M O E=\frac{P L^{3}}{4 b d^{3} \triangle s}
$$

Where:

Moe is modulus of elasticity of elasticity $\left(\mathrm{N} / \mathrm{mm}^{2}\right)$

$\mathrm{P}$ is $\operatorname{load}(\mathrm{N})$

$\mathrm{L}$ is the span of the sample between the machine support $(\mathrm{mm})$

$\mathrm{b}$ is width of the sample $(\mathrm{mm})$

$\triangle \mathrm{s}$ is the change in deflection.

The computation and analysis of raw data obtained from the physical and mechanical properties of WPC produced by the locally fabricated extruder were done using Statistical Package for Social Sciences (SPSS 21 version), Design-Expert 10 (2010 version) and Excel Microsoft 2013. The null hypothesis, used in the analysis of the data says the mean values of the physical and mechanical properties of the WPC samples produced from the three types of wood: Cola gigantia, Ceiba petandra and Milicia exels are all equal, while the alternative hypothesis, 
$H_{a}$, says, the means are not equal at significance level, $\alpha=0.05$. This hypothesis, $H_{o}$ should be rejected if $p-$ value $\leq 0.05$. This is expressed as:

$H_{o}: \mu_{\text {cola }}=\mu_{\text {ceiba }}=\mu_{\text {milicia }}$

$H_{a}:$ at least one $\mu_{1}$ is different

Kindly see appendix 1 and 2 for the pictorial view of the extruder and the WPC samples.

\section{Results and Discussion}

\subsection{Physical Properties}

\subsubsection{Water Absorption}

It was observed from table 1 that after 2 hours of water immersion, the rate of water absorption for SD/PET mix ratio 40:60, 30:70 and 20:80 were high in Cola gigantia and Ceba petandra compared to that of Milicia exels. Whereas, for 20:80 SD/PET mix ratio, Milicia exels did not absorb any water until after 6 hours of water immersion. This trend continues after another 4 hours of water immersion as shown in the bar charts of fig. 1 until 24 hours with Cola gigantia absorbing water the most, followed by Ceiba petandra and Milicia exels absorbing the least.

Table 1: Water absorption of WPC

\begin{tabular}{|c|c|c|c|c|c|c|c|c|c|c|c|c|}
\hline Time & \multicolumn{3}{|c|}{ 2Hrs } & \multicolumn{3}{c|}{ 6Hrs } & \multicolumn{3}{c|}{ 10Hrs } & \multicolumn{3}{c|}{ 24Hrs } \\
\hline $\begin{array}{c}\text { WPC MIX RATIO } \\
\text { (SD:PET) }\end{array}$ & $40: 60$ & $30: 70$ & $20: 80$ & $40: 60$ & $30: 70$ & $20: 80$ & $40: 60$ & $30: 70$ & $20: 80$ & $40: 60$ & $30: 70$ & $20: 80$ \\
\hline Cola Gigantia (\%) & 3.33 & 2.05 & 1.66 & 5.23 & 4.10 & 3.88 & 6.19 & 5.12 & 4.44 & 8.09 & 7.17 & 6.11 \\
\hline Ceiba Petandra (\%) & 2.38 & 1.53 & 1.11 & 3.33 & 3.59 & 2.77 & 4.28 & 4.61 & 3.88 & 5.23 & 5.12 & 4.44 \\
\hline Milicia Exels (\%) & 0.47 & 0.51 & 0.00 & 1.90 & 0.51 & 0.55 & 3.33 & 2.05 & 1.11 & 3.81 & 2.56 & 1.11 \\
\hline
\end{tabular}

It was observed that Milicia exels no longer absorb water at the end of 10 hours of water immersion for 20:80 SD/PET mixing ratio, whereas, Cola gigantia and Ceiba petandra for all the mix ratio continued to absorb water all through the 24 hours water immersion.

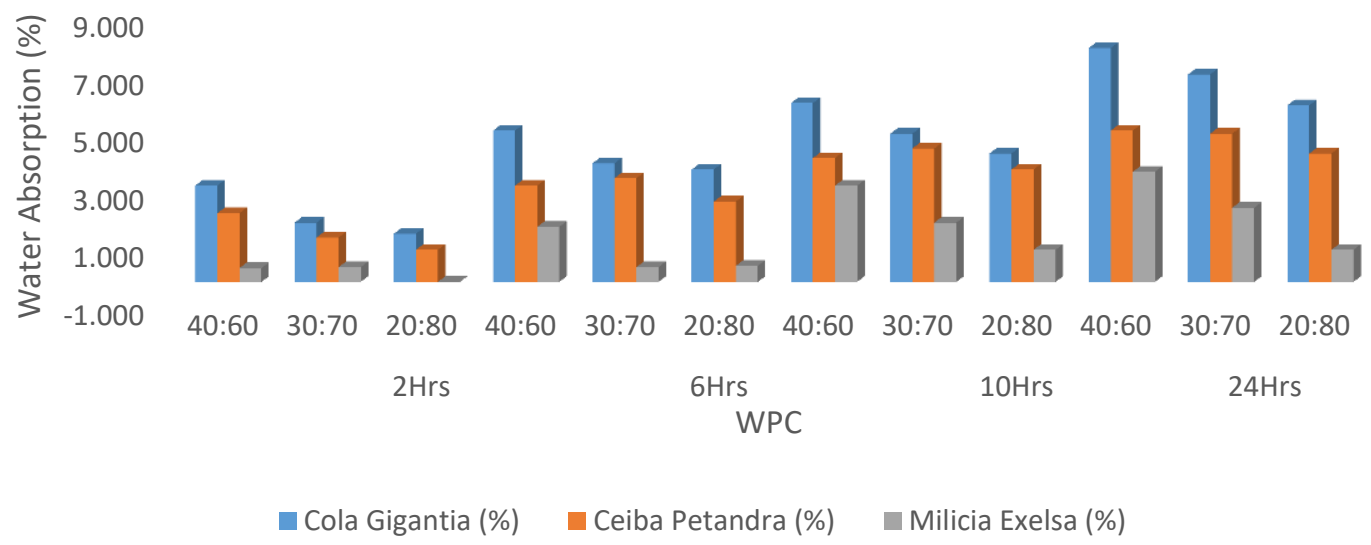

Figure 1: Bar chart of WPC water absorption 
The analysis of variance carried out on the water absorption properties of the WPC samples as presented in table 2 shows that the type of wood, the mix ratio and the time the samples stays in water are all significant at $(\mathrm{p} \leq 0.05)$ level of probability.

Table 2: Anova - water absorption of WPC

\begin{tabular}{|l|l|l|l|l|l|}
\hline Source & DF & Adj SS & Adj MS & F-Value & P-Value \\
\hline Types of Woods & 2 & 93.046 & 46.5228 & 312.56 & $0.000^{*}$ \\
\hline Time (Hrs) & 5 & 68.635 & 13.7270 & 92.22 & $0.000^{*}$ \\
\hline Mix Ratio & 2 & 14.994 & 7.4969 & 50.37 & $0.000^{*}$ \\
\hline Types of Woods*Time (Hrs) & 10 & 5.969 & 0.5969 & 4.01 & $0.004^{*}$ \\
\hline Types of Woods*Mix Ratio & 4 & 1.957 & 0.4893 & 3.29 & $0.032^{*}$ \\
\hline Error & 10 & 2.977 & 0.1488 & & \\
\hline Total & 19 & 180.705 & & & \\
\hline
\end{tabular}

*statistically significant at (p-value $\leq 0.05)$ probability level.

\subsubsection{Thickness Swelling}

Table 3 shows the result of thickness swelling of WPC when immersed in water within 24 hours. It was observed that after 2 hours of water immersion, WPC produced from SD/PET mix ratio 40:60 of Cola gigantia has the highest rate of swelling followed by Ceiba petandra, and Milicia exels, respectively. It was also observed that samples from Milicia exels of SD/PET mix ratio 20:80 did not swell at the end of the 2hours of water immersion, when compared to Cola gigantia and Ceiba petandra for the same 20:80, SD/PET mix ratio respectively.

Table 3: Thickness swelling of WPC

\begin{tabular}{|c|c|c|c|c|c|c|c|c|c|c|c|c|}
\hline Time & \multicolumn{3}{|c|}{ 2Hrs } & \multicolumn{3}{c|}{ 6Hrs } & \multicolumn{3}{c|}{ 10Hrs } & \multicolumn{3}{c|}{ 24Hrs } \\
\hline $\begin{array}{c}\text { WPC MIX } \\
\text { RATIO (SD:PET) }\end{array}$ & $40: 60$ & $30: 70$ & $20: 80$ & $40: 60$ & $30: 70$ & $20: 80$ & $40: 60$ & $30: 70$ & $20: 80$ & $40: 60$ & $30: 70$ & $20: 80$ \\
\hline Cola gigantia (\%) & 5.38 & 3.85 & 1.54 & 7.00 & 6.00 & 3.92 & 7.54 & 6.62 & 4.46 & 9.23 & 7.69 & 5.00 \\
\hline Ceiba petandra (\%) & 3.85 & 1.54 & 0.77 & 6.15 & 3.23 & 2.46 & 6.85 & 3.85 & 3.23 & 6.92 & 4.62 & 3.85 \\
\hline Milicia exels (\%) & 2.31 & 1.54 & 0.00 & 4.46 & 1.54 & 0.77 & 5.00 & 3.69 & 1.54 & 5.08 & 3.85 & 1.54 \\
\hline
\end{tabular}

This trend continues for the three mix ratios as presented in the bar charts of fig. 2 and at the end of 24 hours of water immersion, Cola gigantia swells the most, followed by Ceiba petandra and Milicia exels respectively. 


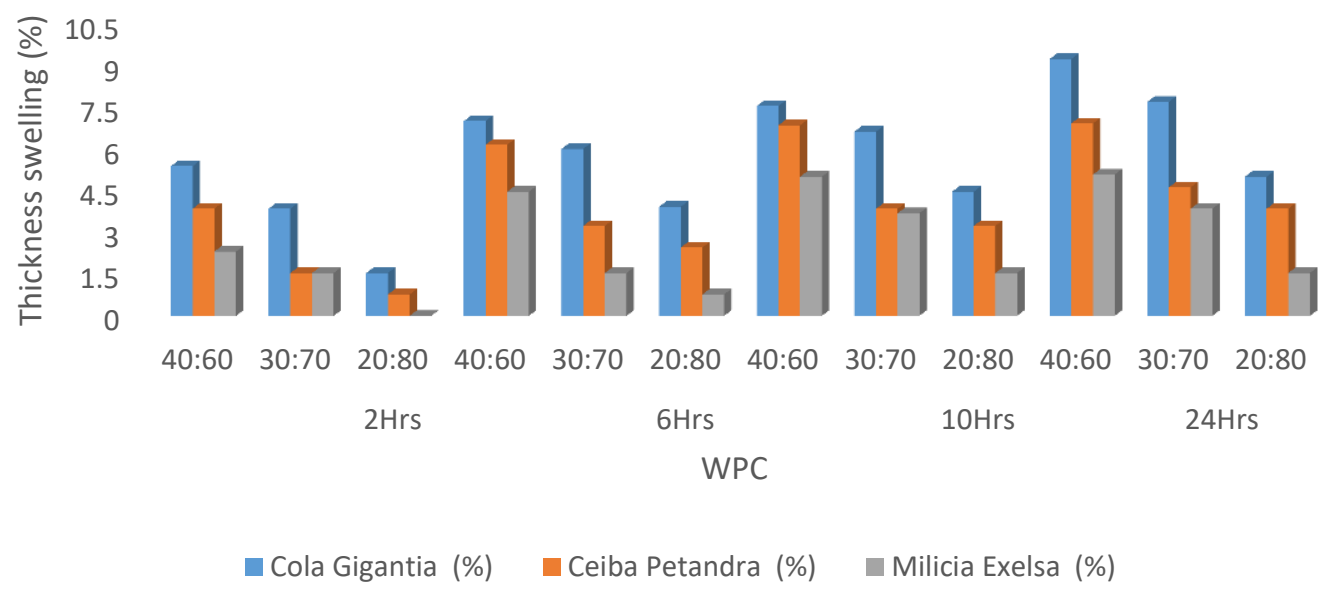

Figure 2: Bar charts of WPC thickness swelling

The analysis of variance at significance level of $p \leq 0.05$ carried out on this result as shown in table 4 revealed that the type of wood, the mix ratio and time the WPC spent inside water have significant impact on the thickness swelling of WPC when immersed in water for 24 hours.

Table 4: ANOVA: Thickness swelling of WPC when immersed in water for 24hrs

\begin{tabular}{|l|r|r|r|r|r|}
\hline Source & DF & Adj SS & Adj MS & F-Value & P-Value \\
\hline Types of Woods & 2 & 87.693 & 43.8463 & 305.96 & $0.000^{*}$ \\
\hline Time (Hrs) & 5 & 52.411 & 10.4822 & 73.15 & $0.000^{*}$ \\
\hline Mix Ratio & 2 & 100.998 & 50.4988 & 352.39 & $0.000^{*}$ \\
\hline Types of Woods*Time (Hrs) & 10 & 2.339 & 0.2339 & 1.63 & $0.003^{*}$ \\
\hline Types of Woods*Mix Ratio & 4 & 4.779 & 1.1947 & 8.34 & $0.001^{*}$ \\
\hline Error & 10 & 2.866 & 0.1433 & & \\
\hline Total & 33 & 252.158 & & & \\
\hline
\end{tabular}

*statistically significant at ( $\mathrm{p}$-value $\leq 0.05)$ probability level;

\subsubsection{Linear Expansion}

Table 5 shows the effect of the mixing ratio, the wood type and time on the linear expansion of WPC when immersed in water within 24 hours. Cola gigantia expanded linearly ahead of Ceiba petandra and Milicia exelsa for the 40:60 mix ratio of SD/PET after two hours of immersing them in water. This trend continues linearly for all the mix ratio as seen in the bar charts of fig. 3 until after 24 hours when Milicia exelsa expanded the least when compared to Cola gigantia and Ceiba petandra for the 20:80 SD/PET mix.

Table 5: linear expansion of WPC

\begin{tabular}{|c|c|c|c|c|c|c|c|c|c|c|c|c|}
\hline Time & \multicolumn{3}{|c|}{ 2Hrs } & \multicolumn{3}{c|}{ 6Hrs } & \multicolumn{3}{c|}{ 10Hrs } & \multicolumn{3}{c|}{ 24Hrs } \\
\hline $\begin{array}{c}\text { WPC MIX RATIO } \\
\text { (SD: PET) }\end{array}$ & $40: 60$ & $30: 70$ & $20: 80$ & $40: 60$ & $30: 70$ & $20: 80$ & $40: 60$ & $30: 70$ & $20: 80$ & $40: 60$ & $30: 70$ & $20: 80$ \\
\hline Cola gigantia (\%) & 0.56 & 0.35 & 0.31 & 0.69 & 0.54 & 0.35 & 0.96 & 0.60 & 0.39 & 1.16 & 0.70 & 0.42 \\
\hline Ceiba petandra (\%) & 0.35 & 0.14 & 0.07 & 0.45 & 0.26 & 0.16 & 0.48 & 0.29 & 0.31 & 0.69 & 0.62 & 0.42 \\
\hline Milicia exels (\%) & 0.14 & 0.07 & 0.00 & 0.25 & 0.07 & 0.07 & 0.27 & 0.31 & 0.10 & 0.27 & 0.32 & 0.10 \\
\hline
\end{tabular}




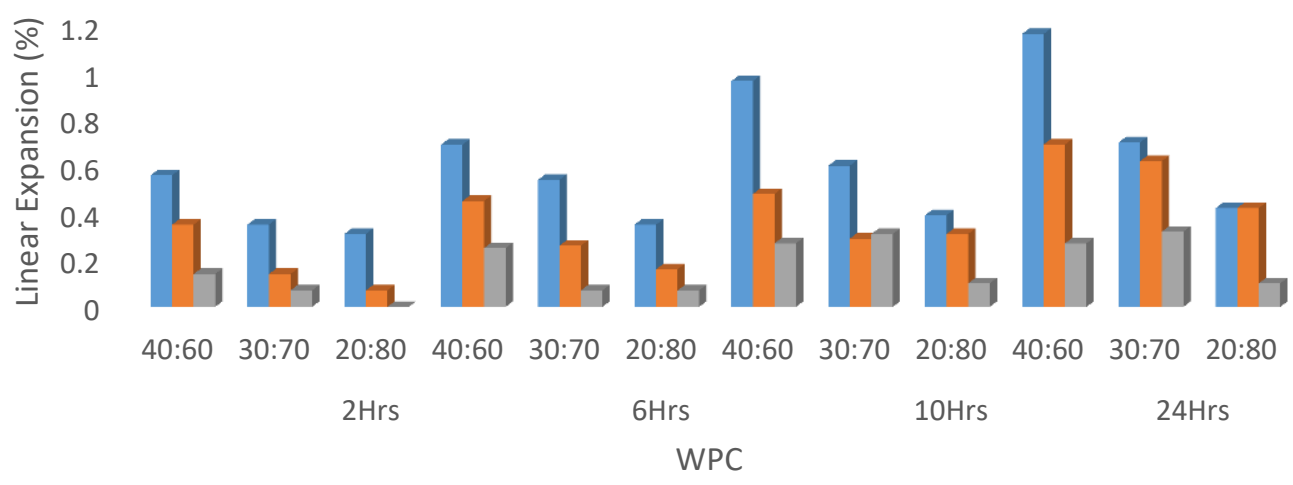

- Cola Gigantia (\%) - Ceiba Petandra (\%) - Milicia Exelsa (\%)

Figure 3: Bar chart of WPC linear expansion

The analysis of variance carried out on the linear expansion test shown in table 6 showed that there were significant difference at $\mathrm{p} \leq 0.05$ as it was observed that the linear expansion was influenced by the type of wood, the mix ratio and the time the WPC spent in water.

Table 6: ANOVA - Linear expansion of WPC

\begin{tabular}{|l|r|r|r|r|r|}
\hline Source & DF & Adj SS & Adj MS & F-Value & P-Value \\
\hline Types of Woods & 2 & 1.70341 & 0.851705 & 131.34 & $0.000^{*}$ \\
\hline Time (Hrs) & 5 & 0.50604 & 0.101207 & 15.61 & $0.000^{*}$ \\
\hline Mix Ratio & 2 & 0.76223 & 0.381114 & 58.77 & $0.000^{*}$ \\
\hline Types of Woods*Time (Hrs) & 10 & 0.06568 & 0.006568 & 1.01 & $0.002^{*}$ \\
\hline Types of Woods*Mix Ratio & 4 & 0.11105 & 0.027764 & 4.28 & $0.001^{*}$ \\
\hline Error & 10 & 0.12970 & 0.006485 & & \\
\hline Total & 33 & 3.33566 & & & \\
\hline
\end{tabular}

*statistically significant at ( $\mathrm{p}$-value $\leq 0.05)$ probability level;

\subsection{Mechanical Properties}

\subsubsection{Modulus of Rupture}

The result of the modulus of rupture carried out on the WPC samples is as shown in table 7 and fig 4. The values of modulus of rupture obtained for the WPC with mix ratio 40:60 SD/PET showed Milicia exelsa having the highest flexural strength ahead of WPC produced from Ceiba petandra and Cola gigantia respectively. This was the trend for the mix ratio 30:70 and 20:80 respectively for the three types of wood investigated.

Table 7: Modulus of rupture of WPC samples

\begin{tabular}{|c|c|c|}
\hline WPC MIX RATIO SD/PET & WPC TYPE & $\operatorname{MOR}\left(\mathbf{N} / \mathbf{m m}^{2}\right)$ \\
\hline $40: 80$ & Milicia exelsa & 7.858 \\
\hline & Ceiba petandra & 7.742 \\
\hline & Cola gigantia & 7.699 \\
\hline $30: 70$ & Milicia exelsa & 7.670 \\
\hline
\end{tabular}




\begin{tabular}{|l|l|l|}
\hline & Ceiba petandra & 7.656 \\
\hline & Cola gigantia & 7.598 \\
\hline $20: 80$ & Milicia exelsa & 7.569 \\
\hline & Ceiba petandra & 7.454 \\
\hline & Cola gigantia & 7.396 \\
\hline
\end{tabular}

\subsection{0}

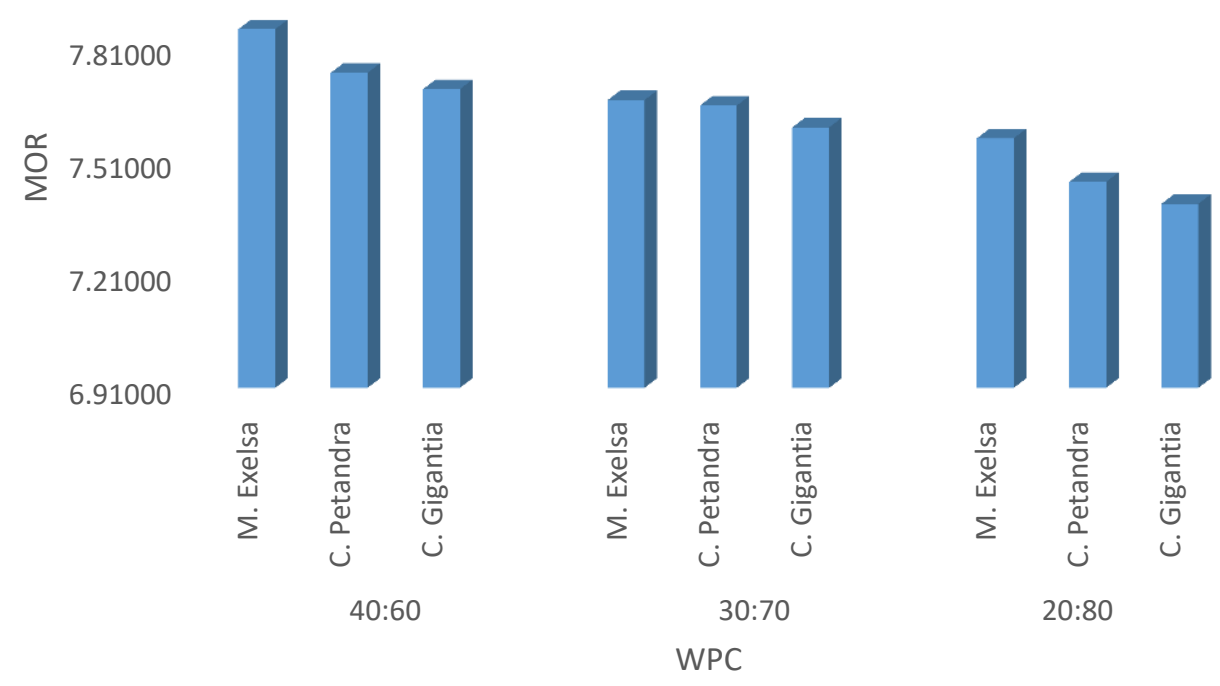

Figure 4: Bar charts of WPC modulus of rupture

The analysis of the variance of the means of the modulus of rupture of the WPC samples at $\alpha=0.05$ significant level for the three types of wood, Cola Gigantia, Ceiba Petandra and Milicia Exelsa been investigated when subjected to flexural test is shown in Table 8. It is seen from this analysis that the $p-$ value $=4.689 e^{-27}<\alpha$ therefore, since, $p-$ value $\leq 0.05$, the null hypothesis that the means are equal is rejected. At the $\alpha=0.05$ significance level, there exist enough evidence to conclude that there is a difference in the mean of the modulus of rupture of the WPC samples when subjected to flexural test.

Table 8: ANOVA - Modulus of rupture of WPC samples

\begin{tabular}{|l|l|l|l|c|c|c|}
\hline Source of Variation & \multicolumn{1}{c|}{ SS } & df & MS & F & P-value & F crit \\
\hline Between Groups & 228.771068 & 2 & 114.385534 & 1864.120806 & $4.68862 \mathrm{E}-27$ & 3.402826105 \\
\hline Within Groups & 1.472679672 & 24 & 0.061361653 & & & \\
\hline Total & 230.2437477 & 26 & & & & \\
\hline
\end{tabular}

*statistically significant at (p-value $\leq 0.05$ ) probability level;

It was observed that the mean value of the MOR of the WPC ranges from $7.396 \mathrm{~N} / \mathrm{mm}^{2}$ to 7.858 $\mathrm{N} / \mathrm{mm}^{2}$. The highest MOR mean was found with the WPC of SD/PET, mix ratio of 40:60 while the least mean was found in the WPC of SD/PET, mix ratio of 20:80. This mean that the strongest WPC were produced at the highest level of wood / plastic ratio. It was also observed that the flexural strength of the WPC increases as the SD content in the composite increases. 


\subsubsection{Modulus of Elasticity}

The result of the modulus of elasticity (MOE) test carried out on the WPC samples is as shown in Table 9 and the bar chart of figure 5. It was observed that the modulus of elasticity of the WPC decreases as the SD content in the composite increases with Milicia Exels ranking first in this regards.

Table 9: Modulus of elsticity of WPC samples

\begin{tabular}{|l|l|l|}
\hline Wpc Mix Ratio Sd/Pet & Wood Type & Moe (N/Mm2) \\
\hline $40: 60$ & Milicia exelsa (Iroko Tree) & 1063.58 \\
\hline & Ceiba petandra (Araba Tree) & 846.77 \\
\hline & Cola gigantia (Oporoporo) & 727.87 \\
\hline $30: 70$ & Milicia exelsa (Iroko Tree) & 1247.80 \\
\hline & Ceiba petandra (Araba Tree) & 1033.07 \\
\hline $20: 80$ & Cola gigantia (Oporoporo) & 884.60 \\
\hline & Milicia exelsa (Iroko Tree) & 1595.48 \\
\hline & Ceiba petandra (Araba Tree) & 1190.55 \\
\hline & Cola gigantia (Oporoporo) & 1007.00 \\
\hline
\end{tabular}

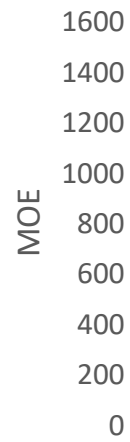

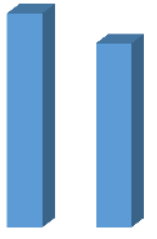

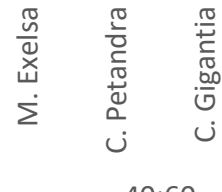

$40: 60$
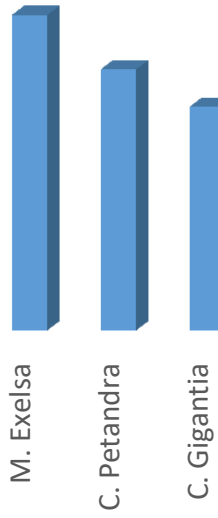

$30: 70$

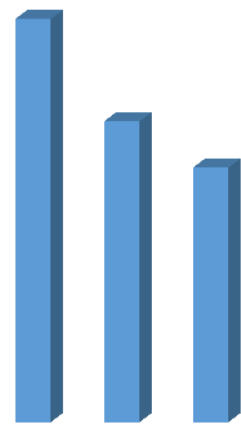

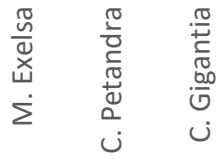

$20: 80$

WPC

Figure 5: bar charts of WPC modulus of elasticity

Table 10 shows the analysis of the variance of the means of the modulus of elasticity of the WPC samples at $\alpha=0.05$ significant level for the three types of wood, Cola Gigantia, Ceiba Petandra and Milicia Exels been investigated when subjected to compression test. It is seen from this analysis that $p-$ value $=4.64 e^{-14}<\alpha$. Therefore, since, $p$-value $\leq 0.05$, the null hypothesis that the means are equal is rejected. At the $\alpha=0.005$ significance level, there exist enough evidence to conclude that there is a difference in the mean of the modulus of elasticity of the WPC samples when subjected to compression test. 
Table 10: ANOVA - modulus of elasticity of WPC samples

\begin{tabular}{|l|l|l|l|c|c|c|}
\hline Source of Variation & \multicolumn{1}{c|}{ SS } & Df & MS & F & P-value & F crit \\
\hline Between Groups & 6311988.759 & 2 & 3155994.379 & 142.9934 & $4.64 \mathrm{E}-14$ & 3.402826 \\
\hline Within Groups & 529701.8609 & 24 & 22070.91087 & & & \\
\hline Total & 6841690.62 & 26 & & & & \\
\hline
\end{tabular}

*statistically significant at (p-value $\leq 0.05$ ) probability level.

It was observed that the mean value of the MOE of the WPC ranges from 879.41 to 1264.34 $\mathrm{N} / \mathrm{mm}^{2}$. The highest MOE mean was found with the mix ratio of 20:80 SD:PET while the least mean was found in the mix ratio of 40:60 SD:PET. This mean that the MOE of the composites decrease along with higher SD loading from $20 \%$ to $40 \%$ in the formulation. It was observed also that for every of the mix ratio, Milicia exelsa has the highest MOE and it was observed that the type of wood and the mixing ratio played significant effects on the modulus of elasticity of the WPC.

\section{WPC Extruder Locally Fabricated}

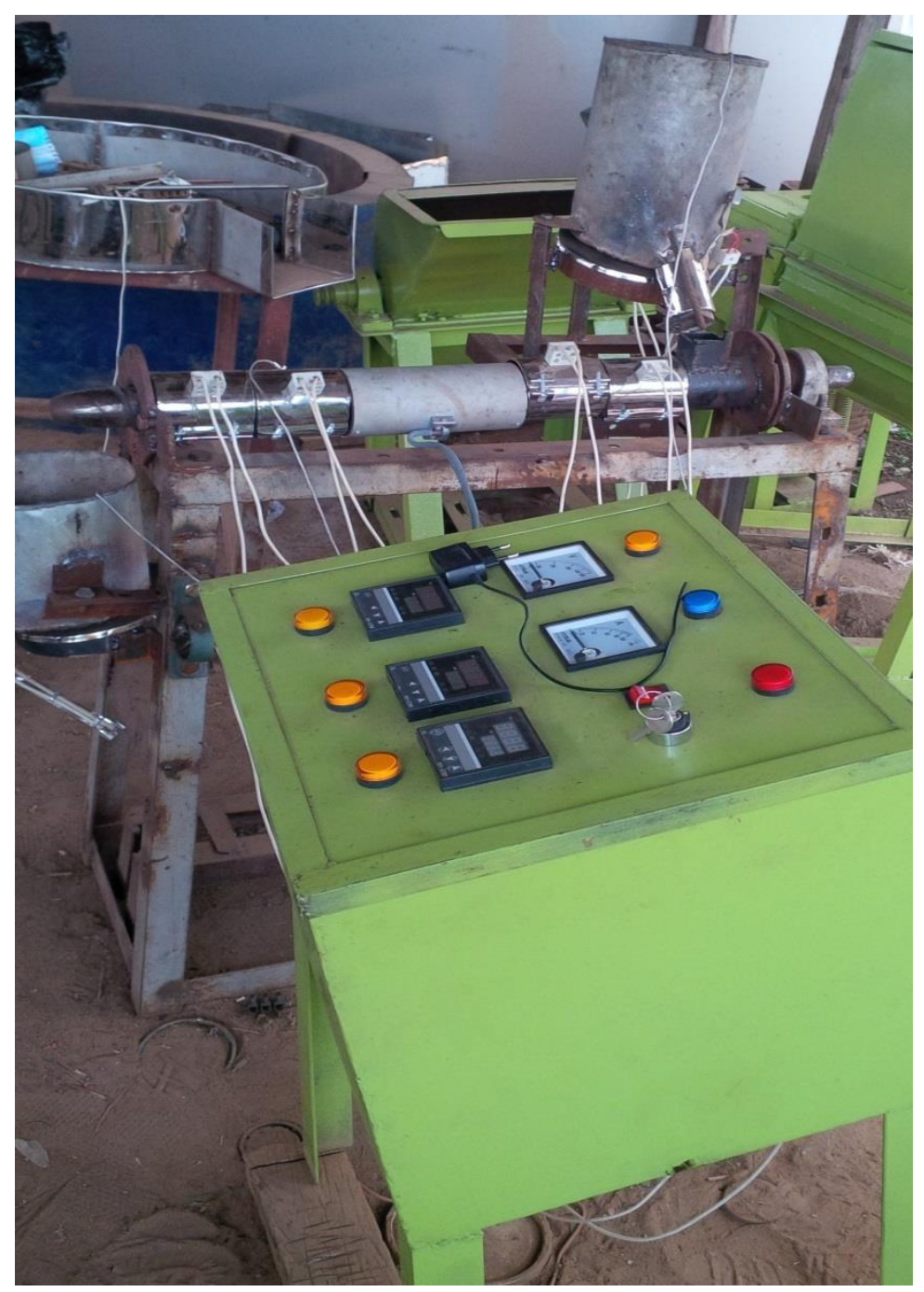




\section{WPC Samples}

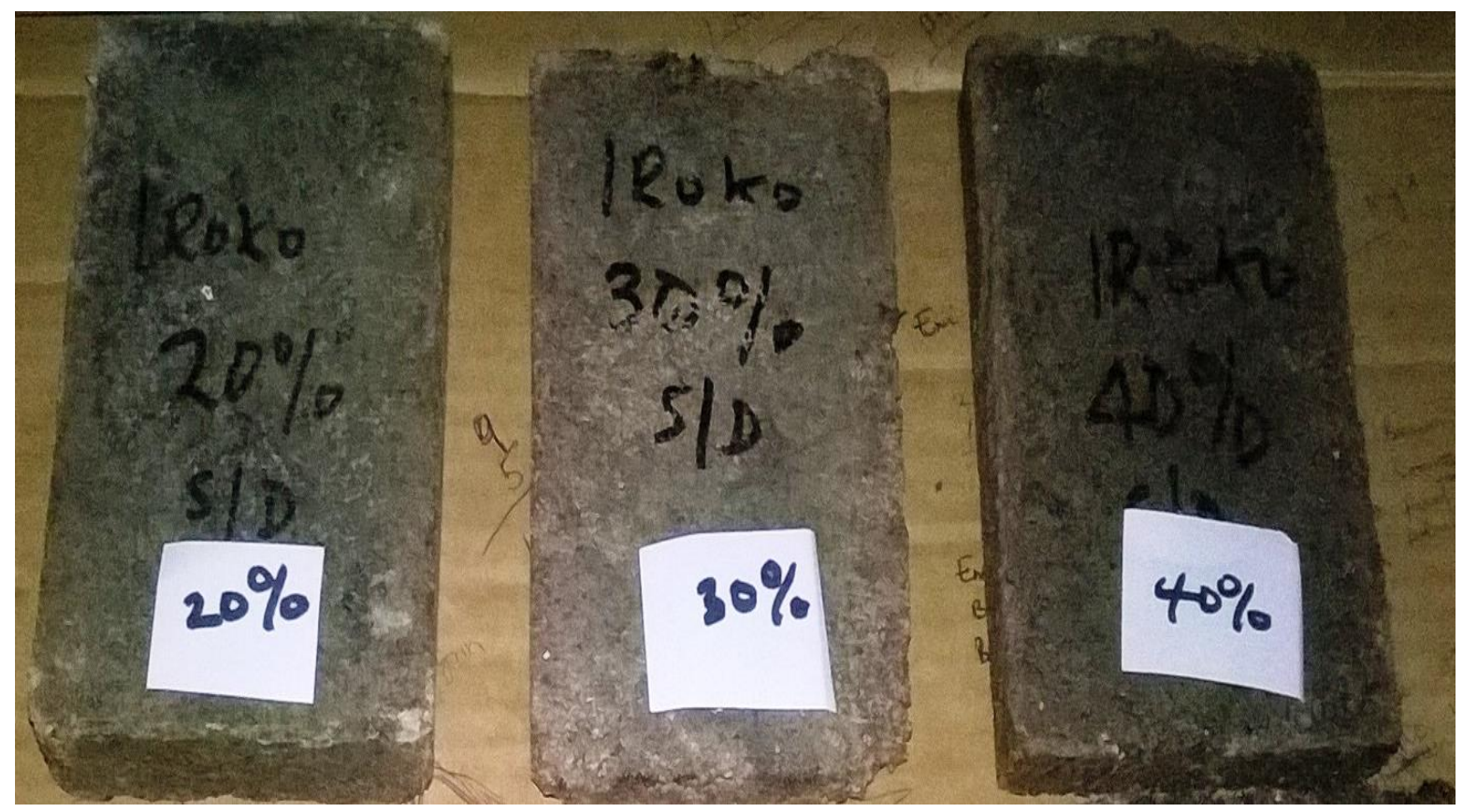

\section{Conclusion}

It is concluded from the research findings and analysis of variance carried out at $0.05 \%$ probability level that the wood type, the mix ratio and the time WPC samples were immersed in water have significant effects on the physical and mechanical properties of the WPC. From the physical test carried out, it was concluded that the 20:80 SD/PET mixing ratio of Milicia exels, WPC was the best in terms of water absorption, thickness swelling and linear expansion when compared to wood species of Cola gigantia and Ceiba petandra for all the mix ratio. In agreement with the study of Izekor and Mordi, (2014), the lesser the SD content in the composite, the lesser the water absorbed and the more the quantity of the plastic content in the composite, the more resistant of the WPC to water uptake which is proportional to thickness swelling and linear expansion. Behzad (2012), Aina et al., (2013) and Izekor and Mordi (2014) has similar observations in their study of the effect of wood / plastic ratio on WPC. Linear expansion decreased with increased plastic content which can be attributed to the hydrophobic nature of plastics as equally observed by Aina et al., (2014). While for the mechanical properties, 40:60 SD/PET mix ratio of Milicia exelsa WPC was the strongest having the highest wood content in term of MOR as equally observed by Adhikary, (2008) and Williams, (2003) that an increase in the wood content leads to increase in the composites flexural strength of the WPC in terms of modulus of rupture. For the modulus of elasticity, SD/PET mix ratio of 20:80 from Milicia Exels has the highest compression test as the MOE decreased along with higher SD loading, this agrees with the work of Rahman et al., (2013) and Oladejo and Omoniyi (2017). Milicia exels of SD/PET mix ratio 20:80 is seen from this research as the best for exterior areas prone to water absorption and dampness such as fences and pool side covering while the SD/PET mix ratio of 40:60 Milicia exels is the best for interior building applications. This study helps to eliminate environmental pollution and it is cost effective in its production since the raw materials are waste resources which will save time, energy and power. 


\section{References}

[1] Adhikary K.B., Pang S. and Staiger M.P. Dimensional stability and mechanical behaviour of wood-plastic composites based on recycled and virgin high-density polyethylene (HDPE). Journal of composite materials 39(1) 2008,:807-815

[2] Aina K.S., Oluyege, O.A. and Fuwape J.A. Effects of indigenous wood Species and plastic/wood ratio on physico-mechanical properties of wood plastic composites. International Journal of Scientific Research in Agricultural Sciences (ISSN: 2345-6795(O)). 3(1), 2016, 11-17.

[3] Aina K. S., Osuntuyi E. O. and Aruwajoye A. S. Comparative studies on physico-mechanical properties of wood plastic composites produced from three indigenous wood species. International Journal of Science and Research. 2(8): 2013, 226 -230

[4] Aina K. S., Osuntuyi E. O. and Aruwajoye A. S. Physico-mechanical properties of wood plastic composites produced from three indigenous wood species. In: Forest and Forest Products; Key to sustainable livelihood Proceedings of the 4th Biennial Conference of the Forest and Forest Products Society. 22nd - 26th April, 2014. pp. 299 - 306.

[5] Akinfiresoye W.A., Olukunle, O.J. and Akintade, A.A. Development of a Wood Plastic Composite Extruder. International Journal of Waste Resources, Vol 7. 2017, Iss.4: 1-4

[6] Akinfiresoye W.A., Olukunle, O.J. and Adelabu D. J. Development of a Waste Plastic Shredding Machine. International Journal of Waste Resources, Vol 7. 2016, Iss.2: 1-4

[7] Behzad K. The effect of plastic type and virginity on properties of wood plastic composites. World Applied Science Journal., 2012, 17(2):168 - 171

[8] Bengtsson M. and Oksman K.. "Silane crosslinked wood plastic composites: Processing and properties." Composites Science and Technology Journal. 66: 2006, 2177-2186.

[9] Bengtsson M., Gatenholm P. and Oksman K. The effect of crosslinking on the properties of polyethylene/wood flour composites. Comp. Sci. Technol. 65: 2005, 1468-1479.

[10] Clemons C. Wood-plastic composites in the United States; The interfacing of two industries. Forest Product Journal., 52(6) 2002, 10-18.

[11] Fabiyi J. S., Armando G. M., Michael P. W. and Peter R. G. "Wood plastic composites weathering: Visual appearance and chemical changes." Polymer Degradation and Stability, 93 (2008): 1405-1414.

[12] Harper D. and Wolcott M. Interaction between coupling agent and lubricants in woodpolypropylene composites. Composites A, 2004, 35:385-394.

[13] Izekor D.N. and Mordi M.E. "Dimensional stability and strength properties of wood plastic composites produced from sawdust of Cordia alliodora (Ruiz and Pav)". Journal of Applied and Natural Science 6(2) 2014,:338-343.

[14] Kehinde O., Godswill M., Anita P. and Tobias R. Nigerian Wood Waste: A Dependable and Renewable Fuel Option for Power Production World Journal of Engineering and Technology, 2014, 2, 234-248

[15] Khandkar S.R., Md Nazrul I., Md Mushfiqur R., Md Obaidullah H., Rudi D. and AbdulKhali H.P.S. Flat -Pressed Wood Plastic Composites from Sawdust and Recycled Polyethylene Terephthalate (PET):physical and mechanical properties. Springerplus Open Journals, 2, 2013, 69.

[16] Klyosov A. A. Wood Plastic Composites. A Book published by John Wiley \& Sons, Inc. Hoboken, New York, NY, USA. 2007, ISBN: 978-0-470-144891-4

[17] Lee S. and Hae S. P. Korean Household Waste Management And Recycling Behavior. Building And Environment Journal 46(5), 2011, 1159-66.

[18] Michael P.W and Karl E. A Technology Review of Wood - Plastic Composites. $33^{\text {rd }}$ International Particleboard / Composite Materials Symposium, Washington State University, Pullman, Washington. USA. 1999. 
[19] Migneault S., Ahmed K., Fouad E. and Abdelkader C. Effects of processing method and fiber size on the structure and properties. Composites: Part A, no. 40 (2009): 80-85.

[20] Mokhtar A.N. Investigating the Mechanical and Physical Properties of Wood Plastic Composites (WPC). The American University of Cairo School of Sciences and Engineering Conference. Spring, 2010.

[21] Nair K.C.M., Thomas S. and Groeninckx, G. Thermal and dynamic mechanical analysis of polystyrene composites reinforced with short sisal fibres. Comp. Sci. Technol. 61: 2001, 2519 2529.

[22] Najafi S.K., Tajvidi M. and Hamidina E. Effect of temperature, plastic type and virginity on the water uptake of sawdust/plastic composites. Holz Roh Werkst 65: 2007, 377-382.

[23] Oladejo K.O. and Omoniyi T. E. Dimensional Stability and Mechanical Properties of Wood Plastic Composites Produced from Sawdust of Anogeissus leiocarpus (Ayin) with Recycled Polyethylene Teraphthalate (PET) Chips. European Journal of Applied Engineering and Scientific Research, 2017, 5 (1): 28-33

[24] Olufemi O. A. and Armando G.M. Evaluation of Wood Plastic Composites from Mahogany and Teak. International Journal of Advanced Engineering Research and Sciences. (4): 2017, 27-32

[25] Oluyege A.O., Ekong A.A., Aguda L.O., Ogunleye B.M., Abiola J.K. and Olayiwola Y.B. Physical and mechanical properties of wood plastic composites Produced from sawdust of ceiba pentandra (1.) Gaertn. and plastic Wastes. Journal of Forestry Research and Management. Vol. 14 (2), 95-112; 2017, ISSN 0189-8418

[26] Soury E., Behravesh A.H., Rouhani E. and Zolfaghari A. Design, optimization and manufacturing of wood-plastic composite pallet." Materials and Design, no.30: 2009, 4183-4191.

[27] Stark N.M. Wood Fibre derived from Scrap Pallets used in Polypropylene Composites.Forest Products Journal; 49(6) 1999, 39-46.

[28] Struktol K. The Effects of Various Additives on the Processing and Physical Properties of WoodFilled PVC. A paper presented at the wood - plastic conference, Baltimore, MD, December, 5, 2000.

[29] Ugoamadi C. C. and Ihesiulor O.K. Optimization Of The Development Of A Plastic Recycling Machine. Nigerian Journal of Technology 30(3): 2011, 67-81

[30] Wechslera A. and Hiziroglu S. "Properties of wood-plastic composites" Building and Environment Journal. 42 (7):2007, 2637-2644.

[31] Winandy J.E., Stark, N.M. and Clemons C. M. Consideration In Recycling Of Wood- Plastic Composites. 5th Global Wood and Natural Fiber Composites Symposium, 27-28 April, 2004 Kassel - Germany.

[32] Yeh S. K., Sushant A. and Rakesh K. G. "Wood-plastic composites formulated with virgin and recycled ABS." Composites Science and Technology, 69: 2009, 2225-2230.

*Corresponding author.

E-mail address: mjemmy2001@ yahoo.com 